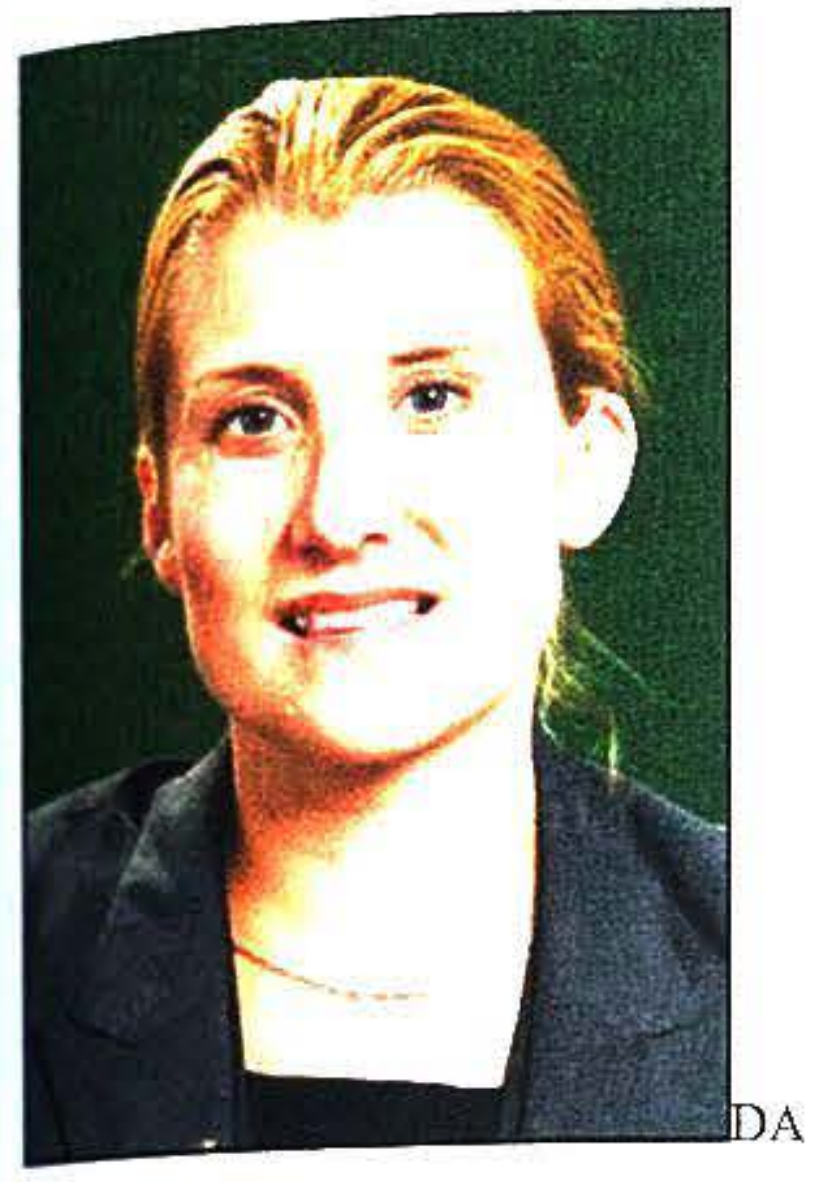

\title{
CHILD LABOUR: WHAT IS HAPPENING IN NEW ZEALAND?
}

\author{
Danaë Anderson, Felicity Lamm \\ \& Erling Rasmussen
}

Auckland University of Technology

\author{
Peter Shuttleworth \& Judith McMorland \\ Action for Children and Youth Aotearoa \\ (ACYA)
}

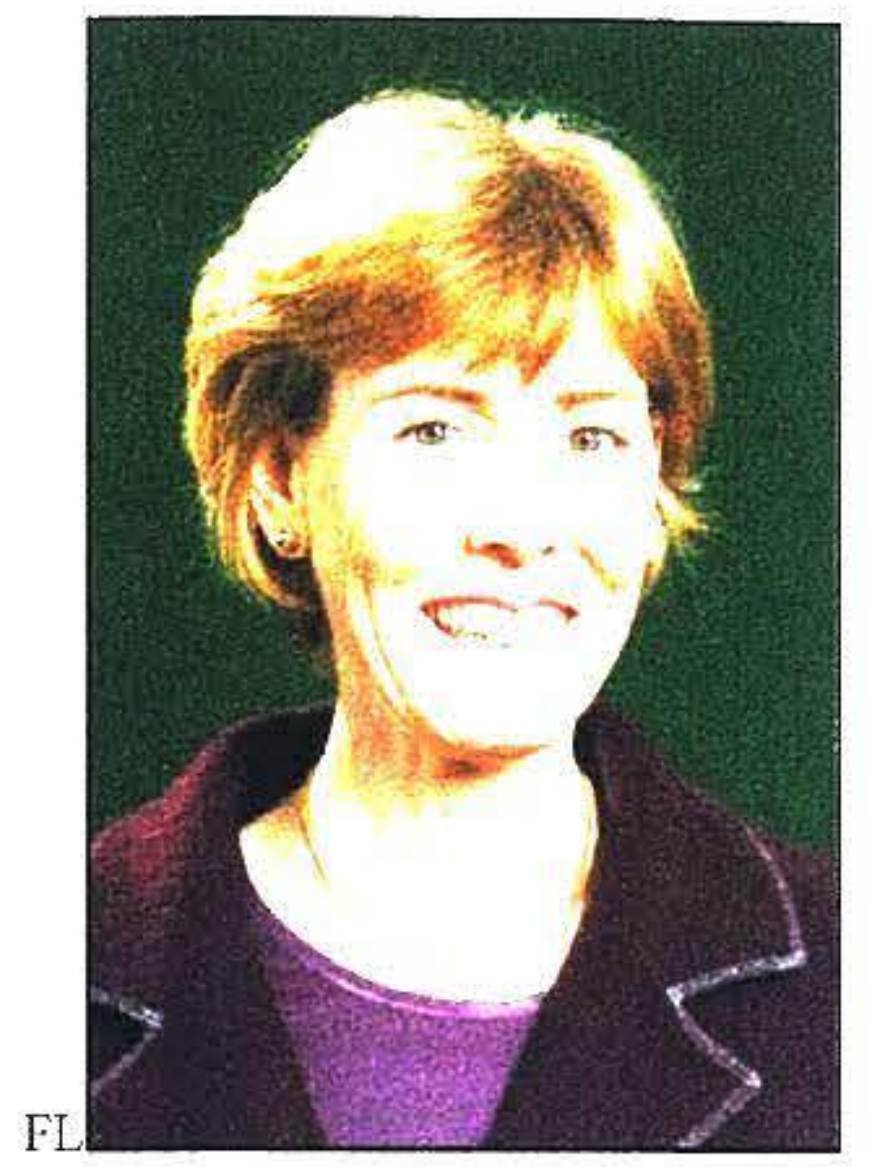

\begin{abstract}
While the rights of New Zealand adult workers have been the primary concern of successive governments and their agencies, the rights of child workers have often been overshadowed. With the recent Government report to the United Nations on New Zealand released, the issues surrounding New Zealand young workers have come to the fore and now require further investigation. The purpose of this paper is to report on Phase One of ongoing research into the working lives and experiences of New Zealand children (those under 18 years). Drawing on existing academic literature as well as government and non-governmental organisations' (NGO) reports and statistics; the paper will present an overview of the status of New Zealand children in terms of: the minimum working age; the minimum wage rates; and occupational health and safety standards. Finally, the paper will outline areas of future research.
\end{abstract}

\section{Introduction}

While acknowledging that successive New Zealand governments have ratified most UN conventions pertaining to the welfare of children, there is no statutory minimum age of access to employment or minimum wage for employees who are under 16 years of age (refer Appendix A). The United Nations and, in particular, its Committee on the Rights of the Child has criticised New Zealand's lack of progress towards child labour issues on a number of points

- New Zealand continues to maintain a reservation of Article 32 of the Convention on the Rights of the Children relating to minimum age of access to employment.

- New Zealand has failed to legislate a minimum wage for child workers under the age of 16 years.

- Children are poorly protected in occupational health and safety matters (for example, there is limited Accident Compensation coverage for child workers ${ }^{1}$ ).

The status of New Zealand's child workers is of particular concern given that there is no legislation specifically covering the wages or conditions of children under the age of 16 years (see Minimum Wage Act 1983, Health and Safety in Employment Act 1992, Employment Relations Act 2000). Further, with the initial NGO United Nations
Universal Periodic Review report covering 2004-2008, and the Government report to the United Nations Convention on the Rights of the Child (UNCROC) on child labour due in April 2009; issues surrounding New Zealand's young workers require further investigation.

The purpose of this paper is to report on Phase One of ongoing research - namely a literature view - into the working lives and experiences of New Zealand children (those under 18 years). The literature review also provides the basis for a submission compiled by Action for Children and Youth Aotearoa Incorporated (ACYA), the umbrella organisation representing various related NGOs. Drawing on existing academic literature as well as government and NGO reports and statistics, the paper will present an overview of the status of New Zealand children in terms of: the minimum working age; minimum wage rates; and occupational health and safety standards. Finally, the paper will provide the rationale and framework for Phase Two of research in this area.

\section{Profile of Child Workers}

Child labour in New Zealand and overseas can be understood in terms of interdependence of children to their families, in which children may have an economic value to their families (Song, in Mizen et al, 2002). Moreover, ideological and political pressures have ensured that 
children's work activities have been channelled into areas of low-paid and low-status work, perpetuating the assumption that children work for pocket money, not wages (Lavalette, 1994: 9). However, it is misleading to believe that child workers are simply 'peripheral wage labourers' (Mizen et al, 2003: 2), incidental to business, but instead should be viewed as contributing to the overall performance of a business.

While there is some evidence that child labour does exist in New Zealand, there is still a paucity of information with most research emanating from non-government sources (Caspi, Moffitt, Wright \& Silva, 1998; Gasson, Gasson, Linzey \& Powell-Chalmers, 2003;), and activist organisations (Child Poverty Action Group 2003; Action for Children and Youth Aotearoa Incorporated, 2003; Catholic Justice, Peace and Development Agency, 2003, 2007). Disturbingly, official data on child labour is not routinely collected and the statistical information available is difficult to analyse (Roth, 2008).

The dominant form of methodology applied to New Zealand child labour is qualitative concentrating mainly on the social implications in this area and detailing children's experiences (e.g. Gasson et al, 2003). There is also some quantitative analysis that focuses on either certain industries or relies on incomplete and unreliable government statistics (e.g. ACC, 2006; Caritas, 2003, 2007). In general, research in this area is limited and often fails to capture what is actually occurring, amongst child workers thus (Goddard \& White, 1982: 466; Barry \& Ready, 2005; Gasson et al, 2003; Bradford, 2007; Caspi et al, 1998; Ehrlich, McClellan, Hemkamp, Islam, \& Ducatman, 2004).

While there is little New Zealand research, most of the overseas studies on child workers are located in the economics discipline, which again provides a myopic view of child workers, (see, for example, Basu \& Van, 1998; Contreras, 2007; Grossmann \& Michaelis, 2007; Rogers \& Swinnerton, 2007). In particular, economic studies on child labour tend to conceptualise the labour of children in terms of supporting impoverished families and assuming children's leisure is an unaffordable luxury. There is, however, some interest in child labour within the discipline of public health (see, for example, Marlenga, Berg, Linneman, Brison \& Pickett, 2007; Roggero, Mangiaterra, Bustreo \& Rosati, 2007).

Nonetheless, overseas research indicates that child workers are typically found in family-run businesses, in the primary sector (agriculture, horticulture, etc) as well as the retail and hospitality industry sectors. Children also constitute a significant part of the informal labour market in both overseas and New Zealand "... often working for very low wages and at times in dangerous and/or illegal working conditions" (Caritas, 2003: 11). Moreover, this group of workers is frequently vulnerable to exploitation for two reasons. First, they are typically not covered by employment legislation. Second, they are often an 'invisible' segment of the labour force and thus are largely ignored in statistical reporting and analysis.

There is some evidence to indicate that exploitation child workers does exist in New Zealand. In a survey nearly 5000 New Zealand children in 2003, Catholi Justice, Peace and Development Agency, (Caritas) reporter that some children were being forced to work to suppor their families, often for very low wages and at times dangerous and/or illegal working conditions. They made the following conclusions

- Children were working in age-restricte employment, including those working with heav machinery, with alcohol, or caring for other children

- There were concerning issues of the health and safety of children, particularly those who reported injuries with potential to cause serious harm, including road accidents, broken bones, and burns.

- Children were often working unsupervised, particularly younger children aged 11-12, who were more likely to work without adult supervision than older age groups.

- Few child workers had formal contracts or union coverage.

Other evidence suggests children compromise their education by being used to replace adult workers. Mizen, Pole and Bolton (2001) found children were often chosen as employees because they offered flexible, low-paid labour and maximised employer's profit margins. Such employment often leaves children largely powerless in the employment relationship (Gasson et al, 2003) as the sectors within which child workers congregate typically have little or no trade union presence (Barry \& Ready, 2005). Further, child workers are predominately employed on a casual, part-time, or temporary basis and few would be protected under either an individual or collective agreement.

In paragraph 1.16 Govt $3 \mathrm{rd} \& 4$ th periodic report, United Nations Convention on the Rights of the Child; 15). it was noted that:

\section{..the research also found that children have a general lack of awareness about their employment rights and whether or not their employers are complying.'}

While the recently instigated Department of Labour Children's Employment Work Programme ${ }^{2}$ seeks to acknowledge and redress issues concerning child workers there are still significant areas of concern in which little progress has been made despite talk of 'ongoing dialogule (Govt 3rd \& 4th periodic report, United Nations Convention on the Rights of the Child, paragraph 1.19). 


\section{Removal of Reservations to the Convention on the Rights of the Child: Convention 138: Concerning the minimum age for admission to employment.}

A number of UN conventions relate directly to child labour. The rationale behind these conventions is the protection of children by minimising their exposure to hazardous working environments and conditions. While New Zealand ratified the UN Convention on the Rights of Children in 1993, it has not signed the ILO Convention 138: Minimum Age Convention (1973) 'Minimum age of access to employment':

'Each Member for which this Convention is in force undertakes to pursue a national policy designed to ensure the effective abolition of child labour and to raise progressively the minimum age for admission to employment or work to a level consistent with the fillest physical and mental development of young persons'. (ILO, 2002)

ILO 138 assumes there is a need for special legislative provision for children and young persons through all spheres of economic activity (Creighton, 1996). The reservation complements the United Nation's Convention on the Rights of Children (UNROC) Article 32(2) requiring that:

\section{States Parties shall...}

a) Provide for a minimum age or minimum wages for admission to employment;

b) Provide for appropriate regulation of the hours and condition of employment;

c) Provide for appropriate penalties or other sanctions to ensure the effective enforcement of the present article'. (United Nations, 1999)

There has been a lack of progress by successive New Zealand governments in clarifying minimum age requirements under UNCROC and removing the existing reservation. The reason for this delay, outlined in the recent report Implementation of the International Covenant on Economic, Social and Cultural Rights (Draft) (2008), has been justified because 'it is both acceptable and common practice for children to engage in work outside school hour's' (Boyd \& Fleming, 2000). This reiterates the commonly held view that children's work in New Zealand is '...socially desirable, since it prepares them for independence and greater responsibility in a way which complements their formal education' (Chetwin, 2002: 2). This idealised description of children's work does not portray the reality of what actually occurs, nor does it acknowledge the fact that New Zealanders have a strong culture of encouraging their children to work, even from a very young age (McKechnie, 1999).

Further debate is needed on what should be the appropriate minimum age for employment in New Zealand. Should it be as the ILO specifies: no younger than 15 , or should it be the age of adult? Could it be more appropriate to set a minimum age of employment at 14, that is, the age at which parents are allowed to leave children unsupervised at home? Currently there are age-related restrictions for "dangerous work' such as operating machinery, working in factories or construction (OSH, 2009). However, further legislation in this area will be a minefield as the public perception is that, for children, working is a largely positive experience. The outgoing Labour government said only a year ago that existing education and safety regulations negate the need for a minimum age for employment (Radio NZ, 2007).

Nevertheless, while forbidding employment for young persons during school hours and at night ${ }^{3}$ may limit the times young people may work, the legislation does not meet the Convention's requirement for specifically setting a minimum age and there are still 'many possibilities of abuse inherent in this approach' (Creighton, 1996: 3).

It would be appropriate for the Government to commit toward an appropriate timeframe for introduction of a minimum age for work and work towards removing its reservation of Article 32 of UNCROC. While adoption of ILO standards is useful in establishing health and safety and minimum age standards for children at work, the ILO has limited power of enforcement in individual countries. It may therefore be more appropriate to describe ILO core standards as giving 'practical application' to the overall principles of the Universal Declaration of Human Rights.

There is logic to this normative approach where best practice' identifies a set of universal rights. Duty to accept and implant these rights falls on all states that are part of the ILO to use their regulatory power and action for enforcement. Moreover, review of New Zealand's employment legislation is required to ensure compatibility with ILO Convention 138 (Murray 2005) so that the law does not discriminate against child workers under 16 years of age in terms of wages and conditions, and that there are no statutory contradictions, for example, between the Minimum Wage Act, 1983 and the Human Rights Act, 1993. 'Equal pay for work of equal value' should be the underlying principle here and the justifications for children being paid less for doing the same work for economic reasons are weak. ${ }^{4}$

But should New Zealand be ratifying this convention? It could be argued there is little evidence of significant exploitation of children in New Zealand, and many types of work may be beneficial for children. Could increased regulation be 'out of step' with community values? Previous governments have shown little commitment to engender change in this area in spite of the Government report to the United Nations Convention on the Rights of the Child (UNCROC) addressing child labour issued in November 2008, and as noted in the NGO initial United Nations Universal Periodic Review report covering 20042008 recently completed. It is unlikely that the change of 
government will signal a change in policy in this area, and indeed there may be lessened regulation in the future.

\section{Minimum wage for work}

in New Zealand there is no statutory minimum wage for employees under 16 years old. The minimum wage for employees aged 16 years and over rose to $\$ 12$ an hour before tax on 1 April, 2008. There is no longer a minimum wage for youth (16-17 years) as of 1 April 2008, changing to the new entrant's minimum wage of $\$ 9.60$ an hour before tax (Department of Labour, 2008). While the Human Rights Commission argues that any minimum wage distinction between 16 and 17 year olds and the rest of the labour force is not justified, children under 16 years are not covered by the Human Rights Act (1993). The validity of paying a 17 year old $60 \%$ of the income of an 18 year old for no other reason than age, regardless of qualifications and capabilities, is difficult to justify in terms of the Human Rights Act. To have no legislation covering those under 16 is cause for concern and fails to acknowledge those under 16 have any rights in the employment relationship.

At a broad level, setting the youth minimum wage must be considered in the context of the Government's overall policy direction in relation to the implementation of UNCROC, and possible ratification of ILO Convention No. 138 on the Minimum Age for Admission to Employment. As a signatory to the Convention, the government will need to work towards ensuring that New Zealand's employment laws are compatible with ILO Convention 138, regulating that all workers irrespective of age are paid equitably. At a domestic level, policy makers are obliged to consider compliance with sections 21 and 22 of the Human Rights Act, which, subject to an existing minimum wage exception in section 30, broadly prohibit discrimination (against persons over the age of 16) on the grounds of age in employment (HRC, 2000: 2). It is recommended that the Human Rights Act is amended to remove unfair discrimination against those under 16 years of age, as currently it allows for discrimination simply on the basis of age.

\section{Health and Safety of Children}

Of particular concern is the health and safety of children undertaking work. While it could be surmised by the Government that '... our existing policy and legislative framework already provides effective age thresholds for entry to work in general, and for safe work', (Govt 3rd \& 4th periodic report, United Nations Convention on the Rights of the Child: 13), this statement overstates the protection current laws provide child workers, particularly with reference to those under the age of 16. In its report entitled The State of the World's Children: Focus on Child Labour (1997: 18), UNICEF argues that children routinely work in hazardous conditions in all industrialised countries and that most of the world's child labourers operate within the informal labour market, working predominately in small business, agricultural, and horticultural sectors. Given that these sectors have a significant presence in the New Zealand economy and that these sectors are overrepresented in the occupational fatality, injury and illness rates, the health and safety of children workers is of great concern.

Statistics on work-related injuries (2006) show that around 300 children under 15 years old visited their general practitioner for a work injury. ACC entitlements or rehabilitation assistance, such as physiotherapy subsidies, are paid to around 10 children under 9; around 15 children in the 10-14 age bracket, and between 1000-2000 young people in the 15-19 age group (ACC, 2006). New Zealand children are also significantly represented in the workrelated fatal injury statistics (Lilley, Feyer, Langley \& Wren, 2004: 1). These injuries often occur when children accompany their parents to their places of work. The most common location of a fatality is on a farm where home and work activities overlap, and informal participation by children in farm work is commonplace (Lilley et al, 2004).

It must be noted that, while these injury statistics indicate that there is cause for concern, there is a general paucity of injury data and what data that do exist are inconsistent and unreliable, especially so for children and child workers. Moreover, there is widespread under-reporting of accident compensation claims, particularly in the informal labour market where injuries may be attributed to non-work accidents as a way of avoiding increased ACC premiums. There is also a lack of detail; that is, there is often little or no information on the ethnicity of the injured child worker or under what circumstances the accident occurred. Thus, ACC figures provide only a partial picture, covering those injuries that were officially reported or led to compensation claims. Not only are the injury statistics compiled on child workers a concern, it is also concerning that the current level of occupational health and safety protection for workers under 16 does not entirely conform to the principles and provisions of the UN Convention on the Rights of Children and related ILO conventions on occupational health and safety.

Under the Health and Safety in Employment Act 1992, the basic tenet is that all workers, irrespective of age or occupation, must be covered by health and safety regulations. With respect to New Zealand's child workers, this is not always the case. Health and safety regulations have not afforded child contractors ${ }^{5}$ the same protection as children working as employees, although this will change on the 1 April 2009 (Caritas, 2008).

However, there is still insufficient regulation of hours of work and conditions: 'there is no law preventing an 11 year old doing 30 hours work each week as long as it is not in school hours, or working a 12 hour day on a Saturday' (Parkinson, 2001: 1). Moreover, the level of legal protection in employment for children varies considerably and is based 
entirely on the age of the worker - that is, adult workers are afforded protection while children are frequently omitted (Boyden et al, 1998).

\section{Conclusion}

There has often been a tendency to focus on visible forms of work but these can obscure the other ways in which children are employed. New Zealand's employment legislation has inherent inequalities in that children are not given the same rights or protection as adults, and the rights of the child are often not given resonance or are minimised in New Zealand discourse. This occurs because child labour is generalised as a developing country's problem. Implicit in this view is that legally restricted employment will have little chance of harming children (Hobbs \& McKechnie, 1997).

However, New Zealand employment law discriminates against young workers in a variety of ways.

There is no minimum age for work.

- The youth minimum wage is lower than the adult minimum wage.

Children under 16 have no minimum wage rate.

The impact of employment may be good or bad and a variety of factors may influence this balance (Hobbs \& McKechnie, 1997). Social and economic issues shape the reasons for work in New Zealand creating a framework where certain types of jobs are seen as routine and suitable for children (Mizen et al, 2003).

However, without statutory protections such as minimum wages and working conditions, young workers risk marginalisation (Human Rights Commission, 2000: 1). Such protection of children and young people at work requires raised awareness of employers, young employees, and their parents about existing or potential health hazards (Vocaturo et al, 2007). While it is acknowledged that not all work is harmful, "children's work needs to be seen as happening along a continuum... And between these two poles are vast areas of work that need not negatively affect a child's development" (UNICEF, 1997: 12).

Finally, it is evident that more research is required, for example in the following areas:

- What is the true extent of child labour in New Zealand?

To what extent is child labour beneficial or harmful to their development? And,

- What is the appropriate level of regulation in order that children can work in safe and useful conditions?

\section{Notes}

1. This is particularly concerning given a large number of children work in the informal labour market, who are not covered by Accident Compensation for lost wages, This assumes that the primary activity for children under 16 is attending school, and that their wages are not necessary for their own or their families' financial wellbeing.

2. The Government is considering the potential ratification of ILO Convention 138 (Minimum Age of Employment). It is also carrying out a work programme to improve knowledge of existing protections for children at work, compliance with children's employment rights, and detection of exploitation when it does occur (Department of Labour, 2008).

3. It is illegal for children under 16 to work during school hours and between the hours of 2200 and 0600) (OSH, 2009; Wilson, 2004)

4. The Government position is that with minimum school leaving age set at 16 years, setting a minimum wage beneath this age limit undermines the school system. The reality is that society accepts that young people gain from part time employment but there is no safeguard from exploitation.

5. Caritas has undertaken two surveys of children's working conditions, and expressed concern in both 2004 and 2007 that children working as contractors were not as well protected as children who were directly employed. Increased protection will hopefully reduce accident and injury rates for child workers (de Jong, 2008).

\section{References}

Accident Compensation Corporation (2006, $1^{\text {st }}$ ed.) ACC Injury Statistics 2006, Section 3.1: All WorkRelated Claims. Retrieved 13 July, 2008, from http://www.acc.co.nz/about-acc/acc-injury-statistics2006/SS WIM2_062980

ACYA (2003) Children and Youth in Aotearoa 2003: the second non-governmental organisations' report from Aotearoa New Zealand to the United Nations Committee on the Rights of the Child. Retrieved July 12, 2008, from www.acya.org.nz

ACYA (2006, 9 October) Submission on Minimum Wage and Remuneration Amendment Bill. Auckland: Action for Children and Youth Aotearoa.

Barry, C., \& Reddy, S. (2005, 25 August) International Trade and Labor Standards: Draft 1.60 Retrieved 8 August, 2008, from http://organizations. 
lawschool.cornell.edu/ilj/symposium/papers/ just_linkage.pdf

Basu, K., \& Van, P.H. (1998) The economics of child labour. American Economic Review, 88(3), 412-27.

Bellamy, C. (1997) The State of the World's Children 1997: Focus on Child Labour. Oxford: Oxford University Press for UNICEF.

Boyd, A. \& Fleming, D. (2000, 11 April) Submission of the Human Rights Commission on the Youth Minimum Wage. Retrieved 12 August, 2008, from http://www.hrc.co.nz/index.php?p=13681\& format $=$ print $\& i d=13689 \&$ keywords $=\&$ month $=\& y e a$ $r=\&$ Submit $=$

Boyden, J. \& Ling, B. (1998) What Works for Working Children. Florence: Rädda Barnen \& UNICEF ICDC.

Bradford, S. (2007, 21 November) Full review of Child Labour Laws needed [Press release]. Wellington: The Green Party.

De Jong, M. (2008) Caritas Welcomes Improved Health and Safety Coverage for Working Children. Retrieved 9 January, 2009, from http://www. caritas.org.nz/?sid=1118

Caritas (2003) Protecting Children at Work: Children's Work Survey. Thorndon: Caritas.

Caritas (2007) Delivering the Goods. Thorndon: Caritas.

Caspi, A., Moffitt, B., Wright, B. and Silva, P. (1998) Earlyfailure in the labor market: child and adolescent predictors of unemployment in the transition to adulthood. American Sociological Review, 63, 42451 .

Chauby, J., Perisic, M., Perrault, N., Laryea-Adji, G. and Khan, N. (2007, March) Child Labour, Education and Policy Options: Working Paper. New York: United Nations Children's Fund.

Chetwin, J. (2002, 12 June) Speech on the Global Report: A Future without Child Labour: Retrieved July 18,2008 , from http://www.dol. govt.nz/pdfs/ILC $\% 2002 \% 20$ Global $\% 20$ Report $\%$ 20 Speech $\% 20$ Future $\% 20$ without $\% 20$ Child $\% 20$ labo ur.pdf

Child Poverty Action Group (2003, $2^{\text {nd }}$ ed.) Our Children: The Priority for Policy. Auckland: Child Poverty Action Group.

Contreras, S. (2008) Child labor participation, human capital accumulation, and economic development. Journal of Macroeconomics, 30, 499-512

Creighton, B. (1996) The ILO Convention No 138 and Australian Law and Practice Relating to Child Labour. Australian Journal of Human Rights. Retrieved October 15, 2008, from http://www. austlii.edu.au/au/journals/AJHR/1996/10.html

Department of Labour (2008) Fact sheet: minimum pay. Retrieved December 4, 2008, fiom http://www. ers.dol.govt.nz/pay/minimum_print.html

Department of Labour (2008) Decent Work New Zealand. Retrieved December 4, 2008, from http://www.dol.govt.nz/services/decentwork/activitie $\mathrm{s} /$ agencies/labour.as $\mathrm{p}$

Ehrlich, P.F., McClellan, W.T., Hemkamp, J.C., Islam, S.S. and Ducatman, A.M. (2004, May) Understanding work-related injuries in children: a perspective in West Virginia using the statemanaged workers' compensation system. Journal of Paediatric Surgery, 39(5), 768-772.

Elliot, K., \& Freeman, R. (2003) Can Labor Standards Improve Under Globalization? Washington: Institute for International Economics.

\section{European Environment and Health Information} System (2007, 8 May) Work injuries in children and young people. Retrieved October 6, 2008, from http://www.enhis.org/object_document/ 04737n27389.html

Gasson, R., Gasson, J., Linzey, T. and PowellChalmers, J. (2003) Young People and Work. Dunedin: Dunedin College of Education.

Goddard, V., \& White, B. (1982) Child Workers and Capitalist Development: An Introductory Note and Bibliography, Development and Change, 13.

Government rejects call for minimum work: Radio, 18 November 2007. Retrieved November 25, 2008, from http://www.childlabour.org.za/newsroom/ news/general/new-zealand-rejects-minimum-age/

Grossmann, H. and Michaelis, J. (2007) Trade Sanctions and the Incidence of Child Labor. Review of Development Economics, 11(1), 49-62.

Health and Safety Executive (2007) Preventing accidents to children on farms. Retrieved October 12,2008 , from http://www.hse.gov.uk/ pubns/as10.pdf

Human Rights Commission (2000, 11 April) 
Submission of the Human Rights Commission on the Youth Minimum Wage. Retrieved July 18, 2008, from http://www.hrc.co.nz/index.php?p= 13681\& format=print\&id $=13689 \&$ keywords $=\&$ month $=\&$ year $=\&$ Submit $=$

International Labour Organisation (2002) Minimum Age Convention, 1973 (No. 138). Retrieved September 11, 2008, from http://webfusion.ilo. org/public/db/standards/normes/appl/appldisplay Conv.cfm?conv $=\mathrm{C} 138$ \&hdroff $=1$ \&lang $=\mathrm{EN}$

International Programme on the Elimination of Child Labour (2008) Hazardous Child Labour. Retrieved 11 October 2008, from http://www. ilo.org/ipec/facts/Hazardouschildlabour/index.htm

Kahn-Freund, O. (1974, January) On Uses and Misuses of Comparative Law, Modern Low Review (37), 1-27.

Lavalette, M. (1994) Child Employment in the Capitalist Labour Market. England: Avebury.

Lilley, R., Feyer, A.M., Langley, J. and Wren, J. (2004, 21 May) The New Zealand child work-related fatal injury study: 1985-1998. The New Zealand Medical Journal, 117(1194): 151-157.

McKechnie, J. and Hobbs, S. (1999, February) Child Labour- The view from the North. Childhood-A Global Journal of Child Research, 6(1), 89-100.

Marlenga, B., Berg, R., Linneman, J., Brison; R. and Pickett, W. (2007, February) Changing the Child Labor Laws for Agriculture: Impact on Injury. American Joumal of Public Health, 276- 282).

Mayhew, C. and Boyle, P. (2001) The Global Expansion of Precarious Employment, Work Disorganisation and Occupational Health: A Review of Recent Research, International Journal of Health Services, 31(2):335-414.

Mendelievich, E. (ed.). (1979) Children at work. Geneva: ILO.

\section{Ministry of Justice (2002) PROTECTING OUR}

INNOCENCE: New Zealand's National Plan of Action Against the Commercial Sexual Exploitation of Children. Retrieved November 21, 2008, from http://www.justice.govt.nz/pubs/

reports/2002/protect-innocence/chapter-1.html

Mizen, P., Pole, C. and Bolton, A. (2001) Hidden Hands: International Perspectives on Children's Work and Labour. London: Routledge Palmer.

Murray, J. (2005) Working Paper 6: External Powers and the Role of the EU in Labour Matters: Work in Progress. Oxford: Institute of European and Comparative Law, University of Oxford. Retrieved 12 September, 2008, from http://www. competition-law.ox.ac.uk/iecl/pdfs/working6mumay.pdf

National Research Council (1998) Protecting Youth at Work: Health, Safety, and Development of Working Children and Adolescents in the United States. Washington: National Academy Press.

New Zealand Government (2008) Implementation of the International Covenant on Economic, Social and Cultural Rights (Draft). : Third periodic reports submitted by States parties under articles 16 and 17 of the Covenant.

New Zealand Health and Safety in Employment Act (1992) Retrieved 15 October, 2008, from http://www.osh.dol.govt.nz/law/hse.shtml

Occupational Health and Safety (2009) Young Workers Fact Sheets: Youth Age Restrictions on Dangerous Work. Retrieved 6 January, 2009, from http://www.osh.dol.govt.nz/publications/ factsheets/youth-age-restrictions.pdf

Parkinson, P. (2001, September) The Child Labour Problem in Australia. Defence for the Child International. Retrieved 13 September 2008, from http//www.dci-auarg/html/parkinson.html

Prout, A., \& James, A. (1997) A New Paradigm for the Sociology of childhood? In A. James \& A. Prout (eds.) Constructing and Reconstructing Childhood. London: Falmer.

Roger, C. \& Swinnerton, K. (2008) A theory of exploitative child labor. Oxford Economic Papers $60,20-41$

Roggero, P., Mangiaterra, V., Bustreo, F. \& Rosati, F. (2007, February) The Health Impact of Child Labor in Developing Countries: Evidence from CrossCountry Data. American Journal of Public Health 271- 276.

Roth, P. (2008, 27 March) Child labour in New Zealand: a job for the nanny state? Retrieved 15 June, 2008

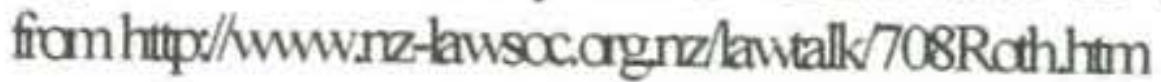

Saphira, M., \& Herbert, A. (2004) The Involvement of Children in Commercial Sexual Activity. Auckland: ECPATNZ.

Saphira, M. (2001) Commercial Exploitation of Children in New Zealand/Aotearoa (CSEC Project). Auckland: ECPATNZ. 
United Nations Convention on the rights of the ChildArticle 32 (1989, 20 November) Retrieved 12 July, 2008, from http://www.unhchr.ch/html/ menu3/b/k2crc.htm

Vocaturo, E., Kunseler, E., Slovakova, G., Ruut, J., Cavoura, O. and Otorepec, P. (2007, May 8) Work injuries in children and young people. Bonn: European Environment and Health Information System.

Wilson, M. (2004, 29 January) Children have rights and protections at work. Retrieved 18 July, 2008, from http://beehive.govt.nz/release/children+ have+rights+and+protections+work

\section{Authors}

Danaë Anderson

School of Business - Management

Auckland University of Technology

Private Bag 92006

Auckland 1142

Anderson.Danae@gmail.com

Felicity Lamm

Associate Professor

School of Business - Management

Auckland University of Technology

Private Bag 92006

Auckland 1142

Felicity.Lamm@aut.ac.nz

\section{Erling Rasmussen}

Professor of Work and Employment

Business School

Auckland University of Technology

Wakefield Street

Auckland

Erling.rasmussen@aut.ac.nz

Peter Shuttleworth

Committee Member

Action for Children and Youth Aotearoa (ACYA)

elaineandpeter@clear.net.nz

Judith McMorland

Honorary Research Fellow

University of Auckland Business School

Secretary

Action for Children and Youth Aotearoa (ACYA)

Judith@colearnz.co.nz

\section{Appendix A: Defining Child and Youth}

The terms used to define 'child' are contentious and inconsistently used in legislation. International conventions tend to define children as aged 18 and under, for example the United Nations Convention on the Rights of the Child defines a child as "every human being below the age of 18 years unless under the law applicable to the child, majority is attained earlier" (Convention on the Rights of the Child, 1989: 6), a definition acceptable to the International Labour Organisation (ILO).

The ILO has no explicit research focus on adolescents as a category, and there is no officially used definition. However, there is focus on the adolescent age group (10-19 years) in relation to the categories of child labour and youth activities, mainly youth employment. The ILO follows the UN definition of youth as the age group between $15-24$ years, but it also recognises that the definition varies according to cultural and institutional factors.

It is worth noting these definitions are further complicated by attempts to define child labour or children's work which have myriad of alternative definitions. Terms such as "child", "adult" and "labour" resist universal definition because of cultural and societal differences from one country to another. Often international organisations and social scientists delineate between 'child work' (not objectionable) and 'child labour' (objectionable) (Chauby, Perisic, Perrault, Laryea-Adji, \& Khan, 2007). The term employment again presents a different set of problems: work may be paid or unpaid, formal or informal, and work may be done for family or non-family. As discussion focuses around UN Part 138 ratification it is appropriate to use UN and ILO definitions, while acknowledging and discussing the difficulties and inconsistencies in use.

New Zealand employment law discriminates against young workers in a variety of ways.

- There is no minimum age for work

- The youth minimum wage is lower than the adult minimum wage

- Children under 16 have no minimum wage rate

(ACYA, 2006) 